\title{
Zika virus was transmitted by sexual contact in Texas, health officials report
}

\author{
Michael McCarthy
}

Seattle

A person in Texas, USA, has become infected with the Zika virus after sexual contact with someone who had acquired the infection while travelling abroad, health officials have reported.

The US Centers for Disease Control and Prevention (CDC) confirmed this as the first known case of Zika virus to be locally acquired in the continental United States during the current outbreak.

Almost all cases of Zika virus infection are transmitted by mosquito bites, although cases of sexual transmission have been reported previously. ${ }^{12}$ Dallas County health department officials said that the traveler had developed Zika-like symptoms after returning to the US from Venezuela, where the virus is circulating. The patient later tested positive for the Zika virus, as did the person's sexual partner, who had not been outside the US.

Several cases of Zika virus infection have been reported in the US in recent weeks, but all had been acquired abroad until now. ${ }^{3}$

Dallas County health officials urged people with symptoms of the infection, which include fever, rash, joint pain, and conjunctivitis, to see a healthcare provider if they had visited an area where Zika virus was present or had had sexual contact with someone who had traveled to such an area.

In a statement, the CDC said that people can protect themselves against spreading sexually transmitted infections by using condoms but that it had not established how long someone infected with the virus could transmit it to others. CDC officials said that the agency would issue guidance in the coming days on preventing sexual transmission of the virus.

In the meantime, the CDC recommended that women who are pregnant or trying to conceive should postpone travel to areas where Zika transmission is ongoing. Pregnant women who live in, or travel to, these areas should talk to their doctor and should follow strict measures to avoid mosquito bites. And women trying to conceive or who are already pregnant should avoid exposure to semen from men who have been exposed to the Zika virus, CDC added.

Public Health England has issued more detailed precautions concerning sexual transmission. ${ }^{4}$ It advises that, in the case of a woman who is pregnant or at risk of getting pregnant, her male partner should use a condom for 28 days after his return from an area of active Zika transmission, "even if he had no symptoms of unexplained fever and rash" and "for six months following recovery if a clinical illness compatible with Zika virus infection or laboratory confirmed Zika virus infection was reported."

The virus's rapid spread, as well as clusters of microencephaly and other neurological disorders associated with infections such as Guillain-Barré syndrome, ${ }^{5}$ has prompted the World Health Organization to declare the outbreak a public health emergency of international concern. ${ }^{6}$

Foy BD, Kobylinski KC, Chilson Foy JL, et al. Probable non-vector-borne transmission of Zika virus, Colorado, USA. Emerg Infect Dis 2011:17:880-2.

2 Musso D, Roche C, Robin E, Nhan T, Teissier A, Cao-Lormeau VM. Potential sexual transmission of Zika virus. Emerg Infect Dis 2015;21:359-61.

3 McCarthy M. First US case of Zika virus infection is identified in Texas. BMJ 2016;352:i212.

4 Public Health England. Clinical advice on Zika: assessing pregnant women following travel; symptoms, transmission (includes sexual transmission), epidemiology. 4 Feb 2016. www.gov.uk/guidance/zika-virus.

5 Dyer O. Zika virus spreads across Americas as concerns mount over birth defects. BMJ 2015;351:h6983.

6 World Health Organization. WHO statement on the first meeting of the International Health Regulations (2005) (IHR 2005) Emergency Committee on Zika virus and observed increase in neurological disorders and neonatal malformations. 1 Feb 2016. www.who.int/ mediacentre/news/statements/2016/1st-emergency-committee-zika/en/. 